\title{
ANWAR SHAIKH AND THE CLASSICAL THEORY OF INTEREST: A CRITICAL NOTE
}

\section{Jan Toporowski}

SOAS, University of London

\begin{abstract}
The Note examines the theory of interest put forward in Shaikh's recent book Capitalism, Competition, Conflict, Crises which presents the classic Ricardian theory of interest, in which the rate of interest is determined by the industrial rate of profit, as the basis for the book's analysis of banking and credit. The Note argues that the classic theory of Anwar Shaikh holds true only under special assumptions, namely when money is a produced commodity, and credit is external to the system of capitalist production. However, in the modern capitalist economy, credit is endogenous to the system of production and distribution. In this more general case, debt and interest have the function of redistributing income, but are unrelated to the rate of profit from production.
\end{abstract}

\section{Keywords: Anwar Shaikh, Rate of Interest, Credit, Banking}

JEL Classification: E11, E43, E44,

'There is, I am convinced, a fatal flaw in that part of the orthodox reasoning that deals with the theory of what determines the level of effective demand and the volume of aggregate employment; the flaw being largely due to the failure of the 
classical doctrine to develop a satisfactory and realistic theory of the rate of interest.' (Keynes 1935, p. 36.)

The publication of Anwar Shaikh's book Capitalism, Competition, Conflict, Crises presents an opportunity to reconsider the classical theory of interest, on which much of the structure of the book is based (Shaikh 2016 chapter 10). This Note takes issue with the classical theory of interest that is the foundation of Shaikh's monetary economics and the theory of bank profit that arises from that classical view. The Note argues that the classical theory of money applies under special assumptions to a very particular capitalist economy in which the monetary sector or banking are external to capitalist production. However, when credit is endogenous to capitalist production, the rate of interest is no longer governed by the rate of profit in the real economy, and the rate of profit of the banking sector does not depend on the actual rate of interest.

This Note does not represent Shaikh's book, or even its core argument. The paper uses the Shaikh's classical theory of interest as the starting point for a critique of that theory. The criticism in this Note proceeds by describing the banking system in which the classical theory of interest holds true and then explaining how, in the credit system that emerged with capitalism, that classical theory of interest does not hold. The Note concludes by arguing that debt and interest perform a purely distributional function in a credit economy. In particular the Note shows that, contrary to the classical view that the rate of interest is determined by the rate of profit, the rate of interest in a capitalist economy is unrelated to the rate of profit from production around which Shaikh builds the analysis in his book.

\section{The Classical Theory of Interest}


By the classical theory of interest is meant the view that the rate of interest is governed by the return on investment undertaken using borrowed funds: a rate of interest higher than this would find no demand for loans, because no capitalist would be able to earn a profit from new investment; a rate of interest lower than the return that may be obtained from capital investment would find capitalists taking out additional loans to undertake new investments: 'the rate of interest... [is] regulated by the profits on the employment of capital, and not by the number or quality of the pieces of metal, which are used to circulate its produce.' (Ricardo 1810, pp. 88-89). In this way the rate of interest determines the level of production, employment (in the case of labour reserves) and investment because that rate marks the limit to which production and investment can profitably be pushed by profitmaximising capitalists. In the classical theory, this limit is set because the interest paid on his loans is a deduction from the profit of the capitalist. In neo-classical theory this link with the marginal productivity of capital is reinforced by the notion that the rate of interest is the opportunity cost of any real investment.

In Anwar Shaikh's book (and in classical economics generally, following the abolition of the Usury Laws), the rate of interest is an exogenous factor, introduced after the determination of production and distribution in a classic, Sraffian way, with an input-output matrix showing the combinations of labour and produced inputs necessary for final production. Real wage rates and rates of profits are inversely related. In Shaikh's book, a process of 'real competition' equalises the rate of profit across all industries. The rate of profit of banks is equal to the common rate of profit minus operating costs ('The loan interest rate directly regulates capitalist accumulation through its role as the benchmark against which the general rate of profit can be measured. But it also determines the bank rate of profit itself. Bank revenue consists of interest receipts on loans, $\ldots$ and bank profit $\ldots$ is the difference between bank revenue and operating costs.' Shaikh p. 448. A similar approach may be found in Kahn 1971, although Shaikh does not cite this work.). The process of real 
competition between capitals brings the rate of profit of banks into equality with the common rate of profit throughout the real economy.

As first enunciated by David Ricardo, it is the rate of interest that is 'ultimately and permanently governed by the rate of profit' (Ricardo Principles p. 297) rather than the other way around. In neo-classical theory, following Marshall, it is the rate of interest that causes capitalists to invest and vary production so that the marginal productivity of capital is brought into line with that rate of interest ${ }^{1}$. Marshall's view remains the conventional wisdom guiding current monetary policy, that considers the rate of interest to be a key variable in determining the equality of saving and investment. Marshall's concept of the relationship between investment and interest then found its way through Keynes's circle into post-Keynesian analysis. In this way, the classical theory of interest retains its influence today ${ }^{2}$.

\section{Capitalist Credit and Finance}

The classical theory may be brought into sharper relief by comparing it with Kalecki's theory of interest, highlighting the fundamental distinction between that theory of interest and the classical theory of interest. In the Kaleckian theory of interest, changes in the rate of interest are non-neutral in respect of income, but neutral in respect of expenditure: a rise/fall in the rate of interest increases/decreases gross income, and transfers income from net debtors to net creditors, but does not change the overall volume or composition of consumption or investment. In the classical theory of interest, changes in the rate of interest are neutral with respect to income, but non-neutral with respect to expenditure. Income remains determined by the real resources available for production and exchange; while changes in the rate of

\footnotetext{
1 'My position is that the mean rate of discount is governed by the mean rate of interest for long loans; that again is determined by the extent and the richness of the field for the investment of capital on the one hand, and on the other by the amount of capital seeking investment... Equilibrium is found at that rate of interest for long loans (and the corresponding rate of discount for short loans) which equates supply and demand.' Marshall 1887, p. 51. See also Wicksell 1899 pp. 138-141.

2 ، ... the size of the gap between the rate of interest... and rates of profit is a material factor in the rate of growth of companies...' (Kahn p. 230).
} 
interest affect the allocation of those resources between consumption and saving, and hence the volume of investment.

The classical theory of interest applies in a situation in which money is a commodity produced separately from the rest of production and distribution (that determines the respective rates of profit and wages). In the case of Marx, the production of gold is included in the sector producing means of production, and therefore using labour and having a rate of profit that corresponds to Ricardo's and Shaikh's rate of profit (Marx 1974, pp. 473-477). More generally, though, the determination of bank profit and interest advanced above would be true in an economy that uses gold as money, where the bank has purchased or produced the gold in the past (so that the cost of the gold had come out of past revenue) and now lends the gold out to capitalists. The bank's total revenue now includes all the interest revenue that it receives on such loans. From that interest revenue the bank's operating (office) expenses are deducted to produce a profit for the owners of the bank. This would also be true of a credit economy in which banks paid no interest to its depositors or bondholders, so that all the interest on its borrowing was available to pay operating costs and distribute to shareholders ${ }^{3}$.

Put like this, it is immediately obvious why Ricardo's and Shaikh's capitalists carry on investing in the real economy: because they cannot earn any money on their bank deposits and other financial assets. This indeed is the 'euthanasia of the rentier' (as already anticipated by Marx 1970, p. 378). However, these are highly unusual circumstances and it is doubtful whether even in Ricardo's time banking outside London, where he worked,

\footnotetext{
${ }^{3}$ In his comments to an earlier draft of this Note, Anwar Shaikh has pointed out that, in his book, zero interest on deposits applies only on demand deposits, but not on savings deposits. If that is the case, then the interest on those savings deposits needs to be deducted from gross bank revenue, in calculating bank profits. Moreover, the interest paid by banks needs to be added to the income of depositors who, in a classical world in which workers do not save, would be capitalists. See comments below at the start of section 3. Kahn, whose 1971 paper anticipates much of Shaikh's analysis, postulated an equity-financed real sector in which the dividend rate on equity is held to be equivalent to the rate of interest.
} 
operated like this. It is true that gold production can be given a separate industrial sector. But in a capitalist economy, the banking sector cannot be treated separately from the system of production and distribution. If it is so treated, for the sake of exposition, then interest and debt cannot be treated as a drain on capitalist income, since capitalists receive interest or derive profits from selling goods and services to recipients of interest who are neither industrial capitalists not workers. Historically, capitalist banking and finance was always more like a 'credit club' of capitalists. The origins of capitalist credit lie in the discounting of bills by 'merchant' or 'country' banks who were originally merely capitalists in possession of sufficient money hoards to be able to use them to buy, at a discount, the IOUs of their business associates (Niebyl, 1946, chapter 3). This is implicit in Marx's analysis of money and interest, and later explicit in Kalecki's first exposition of capitalist financing (Kalecki 1933, pp. 93-98).

This inter-capitalist credit and debt is what distinguishes capitalist credit from its predecessors in usury and traditional money-lending in pre-capitalist societies, or the sovereign debt of the absolutist state within which merchant capitalist credit first emerged. The focus in monetary economics on money as a medium of exchange obscures the key distinguishing feature of capitalist credit, namely that it redistributes money hoards among capitalists, rather than exploiting the rural poor or buying pensions from the state ${ }^{4}$. In a capitalist economy, money comes into exchange through the expenditure of capitalists' money on production, and not as a conventionally, or even legally, accepted token of value in exchange.

The operations of banks as a credit club of capitalists is the foundation of monetary endogeneity. Capitalists have assets, including financial assets like bills, bonds, shares and

\footnotetext{
${ }^{4}$ It is the neglect of the distinction between capitalist credit and debt and pre-capitalist debt, and the income and balance sheet implications of that distinction, that confuses long-term (econometric) studies of debt, such as Reinhart and Rogoff (2008).
} 
government paper, that they can post as security of loans, and those loans create deposits (Withers 1909, Robertson 1928) ${ }^{5}$. It is this financially collateralised lending, rather than the provision of government reserves, as postulated by most Post-Keynesians and reiterated by Shaikh (Shaikh, p. 613), that makes the supply of credit determined by demand, or the ability of capitalists to provide collateral.

The proper test of the classical theory of interest is therefore against this kind of capitalist finance, rather than gold production. As a first approximation to reality, let us, for the sake of simplicity, leave aside the government and foreign sectors, and assume that workers are true proletarians, whose only asset is their labour power. This gives a 'pure' capitalist economy in which the only banking is the 'pure' capitalist credit club. Banks operate holding the deposits of capitalists and advancing loans to them. Banks receive interest from the loans that they advance. But they also pay interest on the funds that are deposited with them. The profits of the banks are the margin between deposit and lending rates of interest multiplied by the value of the balance sheet of every bank, after deducting the operating costs of each bank ${ }^{6}$. Bank profits are therefore unrelated to the level of the rate of interest itself.

However, it should be pointed out that the profits of the financial sector make no difference to profits overall in this capitalist economy: the margin between deposit and lending rates received by capitalists engaged in banking business is obtained at the expense of the profits of non-bank capitalists; the costs of banking business (premises, staff) constitute demand for the output of the non-financial sector and in this way returns to non-bank capitalists a part of

\footnotetext{
5 'We have spoken of bankers and financiers as the makers of credit. But we have also recognized that the chief financial material out of which they make it is the stocks and shares and other certificates of value which represents the capital created by the saving and investing classes. It is thus the growth of the forms of saving which take these financial shapes that enables the increased credit to emerge from the financial factories. All such modern saving can furnish material for the creation of more credit.’ Hobson 1924, p. 89.

6 'The rate of interest that is paid on deposits is always somewhat lower than the rate charged by banks on loans. The difference between these two rates remunerates the bank ...' Wicksell 1899, p. 139.
} 
their profit that those capitalists hand over to bank capitalists under that margin between borrowing and deposit rates of interest.

In this sense, bank expenses may be subsumed under Investment spending (insofar as those expenses are a necessary part of investment) or Capitalists' Consumption (insofar as they are merely the discretionary extravagances that are nowadays associated with financial business) in Kalecki's well-known profits equation ${ }^{7}$.

The more fundamental doctrine of the classic theory of interest is the link between interest and the gross profits of capital. This too can be examined from the 'capitalists' credit club point of view. A literal reading of Marx and the classics suggests that current interest is paid out of current profits. In fact, at any one time capitalists hold loans, and they also hold deposits and bank shares accumulated from past profits. It is out of the total accumulation of profits that interest is paid. But the interest received by capitalists adds to their income. In our 'pure' capitalist economy, the total value of those deposits and bank shares is equal to the total value of the loans in the banking system. If rates of interest are zero, banks make no profit and the capitalists' net income is the profit that they make from production. If interest rates rise, the net income of the capitalists is unchanged: as a class they now pay interest. But their interest income, including the dividends received on their bank shares, has also risen by the same amount. How do they pay that higher interest? They do so by using the deposits that they have in the banking system. Hence, in Kalecki's theory of interest, it is the velocity of circulation of deposits, rather than the volume of business investment, that varies in proportion to the rate of interest on money (Kalecki 1941).

\footnotetext{
${ }^{7}$ The theory may be summarised as follows. In a closed economy, with no government, in a given period, total income $(\mathrm{Y})$ is equal to the sum of profits plus wages $(\mathrm{W}+\mathrm{P})$ which in turn is equal to Consumption plus Investment $(\mathrm{C}+\mathrm{I})$. $\mathrm{Y}-\mathrm{C}=\mathrm{I}=$ Saving. Saving may be divided into the saving of workers $\left(\mathrm{S}_{\mathrm{w}}\right)$ and the saving of capitalists $\left(\mathrm{S}_{\mathrm{c}}\right)$. Similarly, Consumption may be divided into the consumption of workers $\left(\mathrm{C}_{\mathrm{w}}\right)$ and the consumption of capitalists $\left(\mathrm{C}_{\mathrm{c}}\right)$.

Profits are therefore equal to $\mathrm{S}_{\mathrm{c}}+\mathrm{C}_{\mathrm{c}}$. $\mathrm{S}_{\mathrm{c}}$ is equal to total Saving or Investment minus $\mathrm{S}_{\mathrm{w}}\left(\mathrm{I}-\mathrm{S}_{\mathrm{w}}\right)$. Total Profits $\left(\mathrm{S}_{\mathrm{c}}+\mathrm{C}_{\mathrm{c}}\right)$ therefore equal to $\mathrm{I}+\mathrm{C}_{\mathrm{c}}-\mathrm{S}_{\mathrm{w}}$. See Kalecki (1942).
} 
What if the capitalists do not have enough deposits to pay a really exorbitant increase in interest rates? In a credit system they can borrow more, by pledging assets as security against loans, and this corresponds to an increase in their deposits. Providing that banks are accommodating, capitalists will borrow as much deposits as are necessary to maintain interest and debt payments. From those interest and debt receipts they can repay debts. It follows that current industrial profits are not, as the classical theory asserts, the sole source of the means of payment that capitalists have with which to settle their financial obligations. Capitalists have savings, and may borrow against the assets that they possess. This can be illustrated by considering the ultimate Ricardian-Marxian (à la Grossman, perhaps) case where aggregate profit is equal to zero, but interest remains stubbornly positive. Of course this does not mean that no capitalists are making a profit, merely that the profits of some capitalists are balanced by the business losses of other capitalists. Any profits in the banking sector from the margin between lending and deposit rates would be at the expense of overall losses among non-bank capitalists.

In this situation of overall zero profits, capitalists still have deposits (from accumulated past profits and borrowing) and loans from the bank intermediaries. Interest on that borrowing can be paid from deposits held by capitalists who owe interest. Capitalists with credit balances will therefore receive interest income. The higher is the rate of interest, the higher will be the interest paid, and received by capitalists. Bank deposits will be redistributed from net debtor capitalists to net creditor capitalists. What happens when, as a result of successive deposit redistributions, net debtors start to run out of bank deposits to pay interest on their borrowing? In that case, providing they have assets to post as collateral, they can borrow to pay interest, or else borrow without security. The expansion of loans increases also the supply of deposits. As new deposits are redistributed from net debtors to net creditors, the net creditors accumulate the new deposits, which the net creditors can use to repay their loans. The only 
circumstance that can prevent the continuing servicing of financial liabilities in this way is not the failure to generate a profit in production and trade, but a refusal of banks to lend more to net debtors.

The classical theory of interest asserts that capitalists must engage in production and productive investment in order to generate the income that they must pay as interest. The theory does not hold because, in a capitalist economy, capitalists hold savings. Ultimately, through the intermediation of banks, capitalists are indebted to each other. The deposits corresponding to the loans must be in the system and some of those deposits will be available to make interest payments. With a sufficiently elastic credit system, capitalists may pay any amount of interest to each other, and will then receive that same amount of interest (from which to pay interest in future). In practice, of course, the distribution of credits and debts are not the same so that capitalists will be either net creditors or net debtors to each other. Interest and debt are thus ways of redistributing their income among capitalists. They do not require production or investment to generate the profits out of which interest may be paid. ${ }^{8}$

\section{Capitalist credit extended}

In the previous section, it was argued that in a capitalist economy in which production is undertaken for profit, the savings that capitalists have out of their profits may be used to pay interest. With only capitalists and (non-saving) workers in the economy, the banking system is in effect a credit club of capitalists. With their own savings and access to credit, there is no necessity to pay interest solely out of current profits, except in the marginal cases (small enterprises perhaps) where capitalists have no savings. Accordingly, there is no necessary correspondence between the rate of interest and the rate of profit. However, despite being a staple of classical economic analysis, the assumption of a 'pure' capitalist economy, in which

\footnotetext{
8 The process by which this happens in described in Toporowski (2015). Wicksell, who concedes that capitalists hold bank deposits (Wicksell 1899 pp. 138-139), does not draw the logical conclusion from this that those capitalists then also receive interest on those deposits in addition to their income from production and trade.
} 
there are only capitalists and workers, is somewhat abstract. In this section the model of a pure capitalist economy is modified by successive approximations to a more realistic analytical framework to show, contrary to the view of Shaikh and the classics, that bank profits are not determined by the absolute level of the rate of interest, and that the rate of interest is unrelated to the rate of profit.

As a second approximation, the business cycle may be incorporated into this analysis. Shaikh observes the empirical finding first put forward early in the nineteenth century by Thomas Tooke, and later also noted by Wicksell, and which Keynes referred to as Gibson's Paradox (Keynes 1930, p. 198). This is the observation that nominal interest rates rise and fall with prices (and not inversely, as is assumed by the monetary policy consensus today). Accordingly, we should expect capitalists' income from financial operations and assets, their interest income, also to rise in a boom, to some degree because more payments, in relation to operating profit (the difference between sales revenue and direct costs of production) are diverted into interest payments to other capitalists through the banking system as the boom proceeds and interest rates rise. On the one hand the velocity of circulation of demand deposits used as means of payment increases, as rising interest rates make depositors reluctant to keep idle funds in zero-interest demand deposits. On the other hand, the capitalists' income from financial assets increases, with rising interest rates. It then becomes debatable whether the profit that the theoretical capitalist is supposed to be maximising is the operating profit of his enterprise, the net income of the enterprise's productive activities or investment in particular years, or the profits of his enterprise including his net claims on other capitalists.

Taking the system as a whole, we know that those net claims on other capitalists sum to zero (each claim is another capitalist's liability), and classical and neo-classical theory tell us that the aggregate net profit is equal only to the sum of operating profits. But do the 
individual capitalists know this and, from the point of view of the microeconomics of the firm, is it this operating profit that they are maximising, or their operating profit plus their credit and interest claims on each other? Shaikh's and the classics' solution of a banking and financial sector separate from the system of real production and distribution does not really allow for the intermediary function of modern credit. The interest that banks receive is largely passed on to their depositors, bond-holders and shareholders. But in a 'pure' capitalist economy, those depositors, bond-holders and shareholders are other capitalists. Interest and debt may therefore vary the distribution of profit more than influencing the level of production.

In practice, the credit system is of course more complicated. As a third approximation to reality, it is obvious that the capitalists' 'credit club' is itself stratified. On its margins are capitalists who have no financial assets that they can use as collateral against borrowing. These capitalists, mostly small and medium-sized enterprises, are the ones that most correspond to the 'classical' capitalist: borrowing to generate a surplus from production out of which to pay interest and repay loans. Net creditors are concentrated among corporations $^{9}$, and net debtors among small and medium-sized enterprises. The credit system therefore redistributes income from these smaller enterprises to corporations, much as the price system in general redistributes the overall flow of profits to large monopolists. However, smaller businesses, while accounting for the bulk of private sector employment in most countries, undertake only a small proportion of fixed capital investment, the vast bulk of which is conducted by large corporations. This stratification therefore even further reduces any link between the rate of interest and real production and investment.

As a fourth approximation there is now in most countries, next to the capitalists' credit club, a middle class credit club, constituted around and inflated by the residential housing market.

\footnotetext{
${ }^{9}$ Obviously a debt-financed company with real assets cannot be a net creditor. To be a net creditor, a company has to have share capital in excess of its real assets. See Toporowski 2008.
} 
The middle class is here defined by its ownership of assets, principally housing, through whose market the middle class borrows and redistributes bank deposits, paying interest to each other (with appropriate margin deductions for the financial intermediaries). On the margins of this household credit club is the portion of the working class that remains proletarian in being without assets and that least engages with the credit system (Toporowski 2010, chapter 12).

A key implication of the classic theory of interest is that all debt involves a transfer out of the (productive) economy. Shaikh follows the recent financialisation literature in attributing to the rise in gross household debt and debt service payments a growing debt burden on household (pp. 735-6, see also Godley 2000, Wolff 2010, Dodig, Hein and Detzer 2016). The problem with taking gross debt as the indicator of financial stress is that it does not distinguish situations of genuine financial stress, where households face rising debt payments without any increase in income or liquid assets, from situations where debt increases, but is hedged with liquid assets, so that the drain on income is just the margin between income from those assets and the cost of the debt. Most of the debt service payments of the household sector are transfers between households, rather than out of the households sector as a whole. Net debt transfers have, inevitably, been much smaller. This presents a more complex picture than that suggested by the figures on gross indebtedness in any economy. Those transfers between households due to net interest and debt/deposit payments need to be analysed, rather than drawing conclusions from gross debt and gross debt service payments that largely reflect transfers of income on debt contracts derived from the exchange of residential property among better off households. 
As a final approximation to reality, it is necessary to include government borrowing ${ }^{10}$, and credit transactions abroad ${ }^{11}$. These add more complexity to the redistribution of income that credit, debt and interest contracts generate in a credit economy. But they do not change the fundamentally redistributive character of credit, debt and interest.

\section{Conclusion}

Shaikh adheres to the classical theory of interest. This follows from his prior exposition of a theory of production and distribution, which leaves only room for money as an external sector that, through the rate of interest, gives the 'benchmark' rate to which the rate of profit conforms by the process of 'real' competition (of capitals) that equalizes rates across industries. ${ }^{12}$ But modern credit has only a tenuous influence on production and investment,

\footnotetext{
${ }^{10}$ These too should be seen as redistributive mechanisms. The theory of Ricardian Equivalence, which Shaikh does not discuss, can only, like the classical theory of interest, be true in an economy in which the monetary sector is external to the system of production and distribution. In a modern credit economy government debt is simply a commitment to redistribute income from tax-payers to government bond-holders. The flaw in the theory of Ricardian Equivalence is its failure to account for the receipt of future interest and debt repayments that a given government debt implies. A suitable tax on bond-holders should make any government debt manageable. Government debt causes problems when bond-holders are foreign residents and thus the beneficiaries of its redistribution are outside the tax jurisdiction of the government, or when that debt is in foreign currency.

${ }^{11}$ Keynes's 'bancor' project was to be essentially a credit club of governments who kept foreign exchange transactions as book-keeping transfers between themselves using interest rates and exchange rates to manage trade disequilibria. When the actual International Monetary Fund was set up the restriction of the scope of this credit club provided the opportunity for the replacement of the government credit club with the commercial international bank credit club for international transactions. It is this commercial credit that now governs the international monetary system. Shaikh's book considers the purchasing power parity theory of exchange rates and he evaluates critically the theory of comparative advantage in foreign trade. But the breakdown of the Bretton Woods system is attributed to 'neo-liberalism' rather than the failings of the international monetary arrangements set up at Bretton Woods (Shaikh 2016, chapter 11).
}

${ }^{12}$ A referee states that 'the classical theory a-la-Sraffa takes outputs as given and does not problematize how those outputs were determined in the first place... the banks are producing a non-basic service and they will have to modulate their interests on deposits and loans in such a way that their rate of profits on investment in the banking industry come out to be the same as it was determined in the basic goods-goods system independently of the banks...'

The referee indicates that '... I'm not convinced how in a competitive economy, if it is assumed that competition brings about equal rate of profits across industries, could it be claimed that the rate of profits in the banking industry will not be necessarily equal to the rate of profits in the rest of the economy...'

In Shaikh's book this conclusion arises because Shaikh assumes that banks are financed with equity and that the equalisation of the rate of profit arises after a competitive process in which the owners of banks 'modulate their interests on deposits and loans in such a way that their rate of profits on investment come out to be the same as it was determined in the basic-goods system independently of the banks.' This however implies that capitalists 
that influence being largely due to the respect given to Ricardo's theory at the expense of serious consideration of the conditions under which it holds true. Credit and interest in a capitalist economy are contracts to redistribute bank deposits. And if they redistribute bank deposits then it is from net debtors to net creditors rather than from all debtors to some undefined 'rentiers' external to the process of production and distribution. Those net debtors that exist on the lower margins of the business and household credit strata, whose net incomes may be reduced by their debts, are usually marginal to the process of paying interest and debt. It is not the income or profit generated in production that determines the ability to pay interest, but liquidity.

Shaikh argues his case by showing logically that the rate of profit of banks is determined by the rate of interest, and that the rate of interest is brought, by a process of 'real competition' or arbitrage, to equal the rate of profit. However, this is based on special assumptions. This note shows that, more generally, bank profit is equal to the margin between banks' revenue from their assets minus their payments on their liabilities, that is their interest margin, rather than the rate of interest (with appropriate deductions for their operating costs), and the rate of interest is in general unrelated to the rate of profit.

\section{Acknowledgement}

The author is grateful Anwar Shaikh, Clara Mattei, and anonymous referees of this journal, for comments that have improved the argument of this paper. Their generosity leaves the author with sole responsibility for any remaining errors in this paper.

own equity in banks in addition to their ownership of productive means of production and the return on that equity is no longer derived from the profit obtained in industrial circulation. Both of these implications contradict the Marx's theory of interest, or reduce it to the rate of profit in gold production. 


\section{References}

Dodig, N., Hein, E., and Detzer, D., (2016) 'Financialisation and the financial and economic crises: theoretical framework and empirical analysis 15 countries' in Financialisation and the Financial and Economic Crises Country Studies Cheltenham: Edward Elgar.

Godley, W., (2000) 'Seven Unsustainable Processes' Special Report New York: Jerome Levy Economics Institute at Bard College.

Hobson, J.A., (1924) Gold Prices and Wages with An Examination of the Quantity Theory London: Methuen.

Kahn, R.F., (1971) 'Notes on the rate of interest and the growth of firms' in Essays in Employment and Growth Cambridge: Cambridge University Press 1972.

Kalecki, M., (1933) ‘An Essay on the Business Cycle Theory’ in J. Osiatyński (ed.) The Collected Works of Michał Kalecki Volume I Capitalism: Business Cycles and Full Employment Oxford: The Clarendon Press.

Kalecki, M., (1942) 'A Theory of Profits' Economic Journal Vol. LII No. 2, pp. 258-267. Kalecki, M., (1941) 'The Short-term Rate of Interest and the Velocity of Cash Circulation' Review of Economic Studies Volume 2, pp. 97-99.

Keynes, J.M. (1930) A Treatise on Money Volume II The Applied Theory of Money London: Macmillan.

Keynes, J.M. (1935) 'A Self-Adjusting Economic System?' New Republic 82/1055, pp. 35-37. Marshall, A., (1887) 'Minutes of Evidence' to the Royal Commission on the Values of Gold and Silver, in Official Papers by Alfred Marshall London: Macmillan 1926.

Marx, K.H., (1974) Capital A Critique of Political Economy Volume II The Process of Circulation of Capital London: Lawrence and Wishart.

Marx, K.H., (1970) Capital A Critique of Political Economy Volume III The Process of Capitalist Production as a Whole London: Lawrence and Wishart. 
Niebyl, K.H., (1946) Studies in the Classical Theories of Money New York: Columbia University Press.

Reinhart, C.M., and Rogoff, K.S., (2008) This Time Is Different: Eight Centuries of Financial Folly Princeton NJ: Princeton University Press.

Ricardo, D. (1810) The High Price of Bullion: A Proof of the Depreciation of Bank Notes London: Murray, in Sraffa, P. (ed.) The Works and Correspondence of David Ricardo, Volume III, Pamphlets and Papers, 1809-1811 Cambridge: Cambridge University Press 1951.

Ricardo, D., (1817) On the Principles of Political Economy and Taxation in P. Sraffa with M. Dobb The Works and Correspondence of David Ricardo Volume I Cambridge: Cambridge University Press.

Robertson, D.H., (1928) 'Theories of Banking Policy' in Essays in Monetary Theory London: P.S. King, 1940.

Shaikh, A., (2016) Capitalism Competition, Conflict, Crises Oxford University Press. Toporowski, J., (2008) 'Notes on Excess Capital and Liquidity Management' Working Paper No. 549, Annandale-on-Hudson, New York: The Jerome Levy Economics Institute of Bard College, November.

Toporowski, J. (2010) 'Why the World Economy needs a Financial Crash' and other critical essays on Finance and Financial Economics London: Anthem Press.

Toporowski, J., (2015) 'A Kalecki Fable on Debt and the Monetary Transmission Mechanism' London School of Economics, Financial Markets Group Special Paper No. 239 August 2015 ISSN 1359-9151-239.

Wicksell, K. (1899) Interest and Prices A Study of the Causes Regulating the Value of Money translated by R.F. Kahn, London: Macmillan 1936.

Withers, H. (1909) The Meaning of Money New York: Dutton 
Wolff, E.N. (2010) 'Recent Trends in Household Wealth in the United States: Rising Debt and the Middle Class Squeeze - An Update to 2007' Working Paper No. 502, The Levy Economics Institute of Bard College: Annandale-on-Hudson NY 